\title{
Spektakulær krig
}

\section{Kapital, terror og skuespil}

4 Menneskeheden, som engang hos Homer var et skueobjekt for de olympiske guder, er nu blevet det for sig selv. Dens selvfremmedgørelse har nået en sådan grad, at dens egen tilintetgørelse lader sig opleve som æstetisk nydelse af første rang. ${ }^{1}$

Walter Benjamin

64 Hvis den 11. september gjorde noget klart, så var det følgende: at verden er splittet $i$ en uudholdelig opdeling af rigdom og magt. ${ }^{2}$

Jean-Luc Nancy

64 Aldrig førhen har en krig været så mørklagt. Og hvordan kan det være anderledes? En krig og en besættelse, der bygger på løgne, kan ikke tolerere oplysninger, især ikke uafhængige oplysninger. ${ }^{3}$

Giuliana Sgrena

Den 2. april 2008 lancerede den danske statsminister Anders Fogh Rasmussen og NATO's generalsekretær Jaap de Hoop Scheffer på et møde i Bukarest NATO’s egen nye tv-kanal, NATO Channel, der er blevet udviklet af det danske militær i samarbej-de med NATO, og som dagligt skal sende nyheder om NATO på internettet. "Enhver seriøs organisation er nødt til at tage kommunikation meget alvorligt. $\mathrm{Nu}$ om dage er det internettet og YouTube, der er tidens løsen", udtalte Fogh Rasmussen. ${ }^{4}$ Det er meningen, at to professionelle tv-hold skal følge NATO-styrker i bl.a. Afghanistan og lave reportager om udsendte soldaters aktioner. Som NATOchefen forklarede det på pressekonferencen: "Formålet er at vise, hvad vi gør og hvorfor i Afghanistan, Kosovo og andre brændpunkter, hvor alliancen har militære operationer." I løbet af det første døgn var der over to millioner besøgende på siden, hvad NATO selv betragtede som en stor succes. NATO's nye tv-kanal er et glimrende eksempel på, hvorledes krig og billeder er blevet sammenvævede i en 
sådan grad, at det i dag er umuligt reelt at adskille dem.

I dag tager krigsførelse nødvendigvis også form som en kamp med og om billeder, så hvor NATO producerer indslag om succesfulde genopbygningsoperationer - franske soldater indvier en foldboldbane i Kabul - og reportager om udstationerede soldaters hverdag - sergent Mo og hans mænd fra 101st Airborne i frontlinjen i Vardak-provinsen - der svarer Taliban igen ved at udsende videoer, hvor amerikanske spioner bogstavelig talt får hovedet skåret af. Den kamp, der finder sted 'på jorden', fordobles således af en repræsentationskamp, der udspiller sig i forskellige moderne medier som tv og radio eller på internettet. Visuelle repræsentationer indtager både rollen som dokumenterende vidnesbyrd og som symbolske angreb på fjenden, der opildner den hjemlige befolkning og afskrækker andre. I denne kamp drejer det sig for Taliban om at producere og cirkulere skræmmende og gruopvækkende billeder, som overvælder og ryster den vestlige beskuer og mobiliserer de lokale. For NATO's vedkommende drejer det sig om at forsikre en bekymret vestlig offentlighed om, at det hele går godt. I begge tilfælde er det håbet, at reaktionen på kommunikationen er mere emotionel end rationel og velovervejet; billederne, og den måde de bruges på, efterlader nemlig stort set ingen plads til tvivl, de er hurtigt afkodelige og udstikker genkendelige mål. Hvor NATO kæmper for demokrati og modernisering mod en barbarisk fjende, der ønsker at fastholde Afghanistan som et middelalderligt samfund, som huser terrorister, der er Taliban i kamp mod en fremmed invasionsstyrke, der fors $\varnothing$ ger at eksportere ugudelige og amoralske værdier og plyndre og røve enhver form for naturressource.

Den nærværende artikel er et beskedent bidrag til diskussionen af forholdet mellem kapitalisme, stat, krig og billeder post-9/11 med fokus på de nye billedmaskiners rolle i en global politisk kultur karakteriseret af terror og krig. Den overordnede tese er, at nye audiovisuelle repræsentationsteknikker, der tilsammen udgør, hvad vi i forlængelse af den franske situationist Guy Debord kan kalde en 'skærmkapitalisme', er ved at forvandle det politiske, at muligheden for politisk handling langsomt, men sikkert skifter grund og på den måde forårsager en gennemgribende forvandling af måden, hvorpå politiske fællesskaber opstår. Eksemplerne på denne udvikling er både det militariserede frygtfællesskab, som er opstået i den vestlige verden efter terrorangrebet på World Trade Center den 11. september 2001 og den efterfølgende lancerede 'krig mod terror', og det ofte selvmorderiske globale islamiske fællesskab, der gennem henvisninger til ummah og jihad forsøger at præsentere sig som en konkurrent til den vestlige dominans og de fallerede regionale nationalstater.

\section{Forestillede fællesskaber}

Som den tyske kulturkritiker Walter Benjamin argumenterede for i midten af 1930'erne i sin klassiske tekst om "Das Kunstwerk im Zeitalter seiner technischen Reproduzierbarkeit", så muliggør nye reproduktionsteknikker nye perceptionsmåder og nye solidaritetsformer. Benjamin var i sin tid konfronteret med den tyske nazisme og dennes evne til at benytte radio og film i skabelsen af en iscenesat politisk offentlighed, hvor, som Benjamin formulerer det, massen kom til udtryk, men ikke 
til sin ret. ${ }^{5}$ Især filmen havde ifølge Benjamin ellers muliggjort en kritisk kollektiv reception, der åbnede for en progressiv tilegnelse af den moderne kunst og de nye teknikker med henblik på skabelsen af et socialistisk samfund. Til Benjamins store fortrydelse var det imidlertid nazismen, som viste en forbløffende forståelse for de nye medier, med hvilke den skabte et moderne racistisk fællesskab, der forenede sig om Hitler - der i form af billeder og portrætter var til stede overalt - og idéen om den ariske races primat, som fik konkret form i udryddelseslejrene, hvor det nazistiske regime videreudviklede metoder anvendt i kolonierne. ${ }^{6}$ Trods nazismens på mange måder forældede og reaktionære verdenssyn trak den veksler på moderne teknologi i fjernelsen af interne og eksterne fjender og i skabelsen af et nationalt fællesskab. I lejrene blev racens fjender aflivet ved hjælp af moderne teknikker og organiseringsformer.7 Samtidig kreerede nazismen en veritabel moderne underholdningskultur, hvor hagekorset fungerede som en form for logo, der bragte orden i en kaotisk verden og udstyrede den enkelte tysker med identitet. Som den amerikanske kulturhistoriker Alice Yeager Kaplan i forlængelse af Benjamin har redegjort for, så oplevede det racistiske nazistiske subjekt sig decideret som (del af) en film. ${ }^{8}$ Nazismens brug af nye kommunikationsteknikker som film og radio var altså allerede i 1930'erne i stand til at skabe solidaritetsformer og national bevidsthed på en anden og mere gennemgribende måde, end trykketeknikken formåede det i det 19. århundrede, hvor trykkekapitalismen ifølge den engelske historiker Benedict Anderson muliggjorde fremkomsten af nationale fællesskaber og nationalstatsmodellen. ${ }^{9}$

Med efterkrigstidens konsumsamfund blev den teknologiske udvikling intensiveret, og nye varebårne fællesskaber blev en realitet. Denne udvikling blev i samtiden forsøgt kortlagt af såvel de engelske Cultural Studies, som dele af Frankfurterskolen med Herbert Marcuse i spidsen, men det var frem for nogen den franske situationist Guy Debord, der var i stand til at analysere det skifte, der fandt sted på dette tidspunkt. Debord benævnte det samfund, som opstod, skuespilsamfundet, hvormed han påpegede, at den menneskelige forestillingsverden nu var hinsides den enkeltes og artens kontrol, eftersom den politiske økonomis feticheringsevne havde underlagt sig det spektakulære i kommunikationen. Den spektakulære markedskapitalisme udøvede ifølge Debord en ny type kontrol, der passiviserede befolkningen ved hjælp af forførende billeder og hypnotiske repræsentationer. Billeder holdt et splittet samfund sammen. Det kapitalistiske samfund var, som allerede Karl Marx beskrev det, kendetegnet ved splittelse. Kapitalismen destruerer alle fællesskaber $i$ en kontinuerlig innovationsbevægelse, hvor tidligere ritualer, omgangsformer og kommunikationsformer løbende erstattes af nye former, der igen erstattes af andre i en altomfattende transformationsproces. Idet individet rives løs fra tidligere fællesskaber, tømmes vedkommende for indhold og fyldes derfor konstant med billeder, der legitimerer de kapitalistiske produktionsforhold og det kapitalistisk definerede arbejde.

Med teorien om skuespillet fulgte Debord således i Marx' fodspor og analyserede, hvorledes hele verden var ved at blive reduceret til vareværdiens adskilte verden, hvor der ikke var andre forhold end mellem objekter, og hvor menneskene tenderede til at blive reduceret til tilskuere. Skuespilsamfundet var ifølge Debord kendetegnet ved, at levende erfaringer var blevet erstattet med passiv kontempla- 
tion af billeder. Som Guy Debord plagierende Marx formulerer det i den første tese i La Société du Spectacle: "I de samfund, hvor de moderne produktionsbetingelser hersker, viser hele livet sig som en uhyre ophobning af skuespil. Al direkte oplevelse har fortonet sig i en forestilling." ${ }^{\text {Io }}$ I den spektakulære markedskapitalisme har vareformen bredt sig ud over hele samfundet. Skuespillet er pengenes anonyme totalitære orden, en affolket verden hinsides menneskenes indflydelse. Det er vareverdenen som repræsentationsproces, dens bliven verden.

Som Marx tidligere havde beskrevet det i Das Kapital, synes varerne at opnå kuriøse 'sociale' relationer takket være deres bytteværdi. Med den spektakulære varekapitalisme var varerne blevet til billeder, til hieroglyfiske repræsentationer af sociale forhold. Efterkrigstidens nye reproduktionsteknologier, i særdeleshed tvmediet, viste sig at være ideelle til at systematisere og sprede skin og tæppebombe livet med en kontinuerlig masse af reklamer, jingles, slogans og repræsentationer, der overvældede den enkelte. "I Som Debord formulerer det: "Skuespillet optræder som en enorm, indiskutabel og utilnærmelig positivitet. Det siger intet andet end at 'det, der vises, er godt, og det, der er godt, vises.."

Denne udvikling, som Debord kortlagde i 1960'erne, er blot taget til i styrke siden da, og den nuværende skærmkultur, hvor den enkelte konstant bombarderes med billeder, slogans, diagrammer og kort som led i en eksplosiv symbolsk produktion, skaber i endnu højere grad mulighed for konstruktionen af nye imaginære fællesskaber eller måske snarere for genkomsten af gamle fællesskaber, der formår at benytte sig af de nye teknikker, der er til rådighed. Lige nu er det nok mest det sidste, vi er konfronteret med: genkomsten af gamle fællesskaber, selvom både den amerikanske nation forenet i kamp mod terrorismen og den radikale islamismes fællesskab forsøger at overbevise os om noget andet.

\section{En global billedoffentlighed}

Billeder spiller altså en stadig større rolle i skabelsen, formidlingen og evalueringen af politiske konflikter og begivenheder, og krige er i dag i endnu højere grad end tidligere båret af repræsentationer og retorik. Som den dekonstruktive amerikanske menneskerettighedsforsker Thomas Keenan skriver: "[V]i kan ikke forstå, ej heller oppebære et virkeligt politisk forhold til invasioner og krigsforbrydelser, militære operationer og paramilitære rædsler [...] hvis vi ikke er opmærksomme på den vigtige rolle, som billedproduktion og billedstyring spiller i disse." ${ }^{\text {”s }}$ Publiceringen af en række tegninger i en i global sammenhæng ganske ubetydelig dansk avis - tegninger der havde til formål at stigmatisere danske muslimer som led i den såkaldte 'kulturkamp' - er blot et eksempel på, hvorledes billeder pludseligt cirkulerer på globalt niveau og indgår i helt andre kontekster end den 'oprindelige' og ansporer til voldelige modreaktioner eller legitimerer allerede udførte handlinger. I dag kan et billede på den måde opnå global cirkulation, ikke mindst takket være platforme som YouTube, MySpace, LiveLeak og blogs. Globaliseringens nye billedmaskiner som tv, internet og mobiltelefoner har således på den ene side udstyret mange med evnen til at producere repræsentationer, og på den anden side gjort det svært at orientere sig i den overvældende billedmasse og kritisk fortolke de cirkulerede repræsentationer. 
Men samtidig med, at vi således kan tale om eksistensen af en egentlig global billedoffentlighed, eller måske snarere om at få, bestemte billeder cirkulerer globalt og fortolkes i en række lokale kontekster, så er omgangen med billeder blevet underlagt mere og mere kontrol. Der er store såvel økonomiske som politiske interesser på spil, og både stater, politiske og religiøse grupper og multinationale firmaer fors $\emptyset$ ger at besidde, styre og kontrollere billederne. Disse styringsfors $\emptyset$ g gælder naturligvis især billeder, der har at gøre med krig og politiske konflikter. Den ovenfor omtalte NATO-kanal er blot et eksempel ud af mange på, hvorledes militæret selv forsøger at tage hånd om billedproduktionen og på den måde kontrollere, hvad der er synligt.

\section{Det spektakulære nederlag}

Terrorangrebet den 11. september 2001 var et glimrende eksempel på denne udvikling, hvor begivenheders billedkarakter er central. Mohammed Atta og hans terrorcelle formåede med indflyvningen i de to tvillingetårne effektivt at erobre verdensscenen og skabe billeder, der både tryllebandt og vækkede rædsel jorden rundt. Som Retortkollektivet skriver, var aktionens præmis, at et billede i dag er langt mere effektivt end tusind ord. ${ }^{\mathrm{I}}{ }^{4} \mathrm{Tv}$-seere over hele kloden så med vantro billederne af det andet fly, der som et glinsende, men utydeligt flyvende sølvobjekt kom ind i billedet fra venstre og fløj direkte ind i det andet tårn, sydtårnet, og udløste en rød, orange og sort ildkugle mod en klar blå efterårshimmel. En times tid senere styrtede de to tårne sammen i et inferno af stål, glas og røg. Referencen til utallige katastrofefilm fra Hollywood lå ligefor, men her var der tale om en liveudsendelse, hvor tusinder af mennesker blev dræbt. Tv-skærmens uvirkelighed føltes pludselig helt virkelig og knyttede den enkelte seer til en verden udenfor. Som den slovenske filosof Slavoj Žižek skriver, viste den vestlige verdens sikre og rene virtuelle kapitalisme sig pludselig at indeholde det ørkenlandskab, der traditionelt er på sikker afstand i ‘den tredje verden'. ${ }^{15}$ Med terrorangrebet på World Trade Center, der lå lige midt i finansdistriktet på Manhattan, blev New York forvandlet til "virkelighedens ørkenlandskab", og den filmiske repræsentation, der sikrede, at ørkenen var sikkert placeret i den underudviklede del af verden, blev anfægtet. Vestens antiseptiske kuvøseunivers blev smadret, og vi så det alle sammen.

"Vi er alle newyorkere", lød det støttende og rædselsslagent fra en lang række regeringer og mennesker verden over. Andre steder som i Beograd, Jakarta og på Vestbredden blev terrorangrebet derimod fejret: "Vi er alle al-Qaeda". Det lykkedes i den forstand for Bin Laden og al-Qaeda at give muslimer et verdensbillede og vække et muslimsk fællesskab til live, hvor anakronistisk det end er i Bin Ladens version med al sin kvindefjendskhed og antisemitisme. ${ }^{16}$

\section{Terrorisme som kommunikation}

Som den amerikanske politolog Jonathan Barker skriver, er terrorisme strategisk brug af vold mod civile, ofte udført af stater, men også af personer eller grupper, som tænker som stater, uanset hvor marginale eller fattige de er. ${ }^{17}$ Terrorister $ø$ nker 


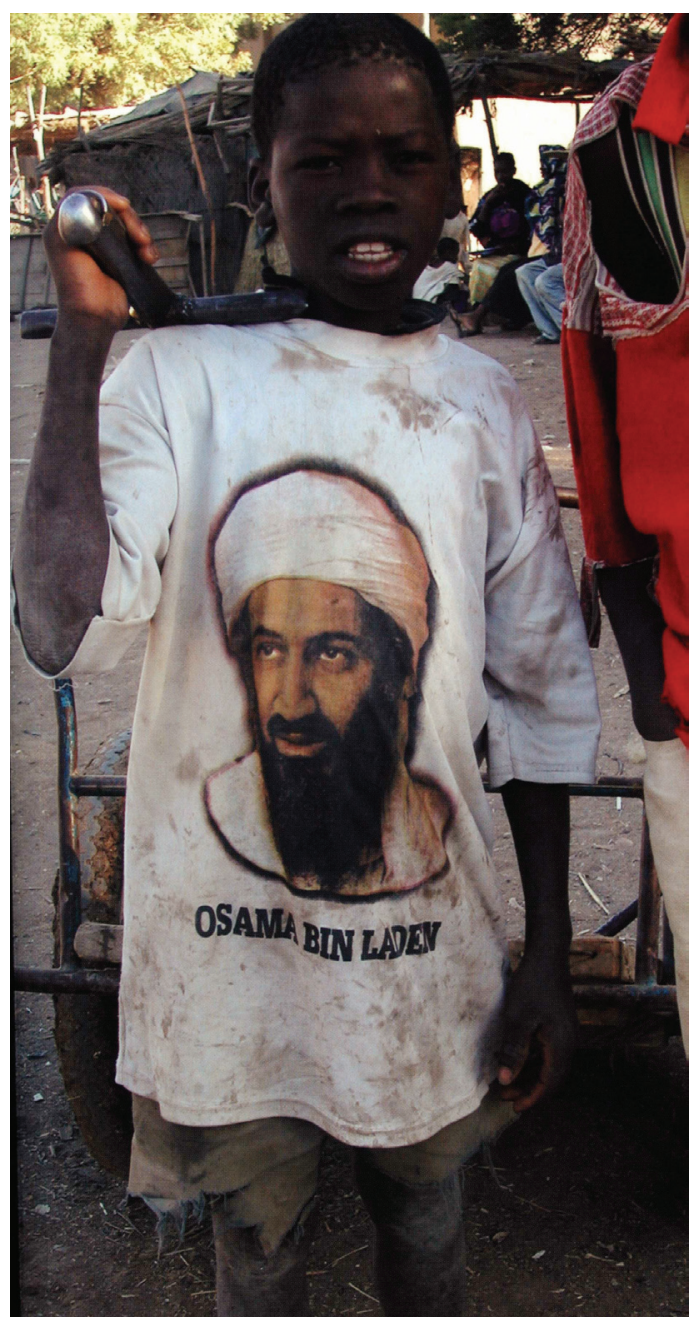

at dræbe og lemlæste, men også at demoralisere og sprede det budskab, at ingen er sikre. Terrorisme er med andre ord en kommunikationsform. Margaret Thatcher havde lært lektien allerede i 1980'erne konfronteret med IRA: “Omtale er terrorismens oxygen. ${ }^{{ }^{18}}$ Det handler om at komme i nyhederne og brænde et billede af smerte og rædsel fast på befolkningens nethinde. Som den franske filosof Jacques Derrida understreger, er relationen mellem terrorismen og eksponeringen af den essentiel: 'Den snævre, for snævre, betydning af ordet 'terrorisme', som vi almindeligvis antager i dag, sættes på forskellig vis i omløb i den diskurs, der behersker det offentlige rum, først og fremmest gennem mediernes teknoøkonomiske magt." Som i tilfældet med de to tårne i New York er taktikken ofte omkostningseffektiv og forfærdelig succesfuld. Det viser historien, hvor selv store kolonimagter har måttet give op og trække sig tilbage konfronteret med terrorangreb udført af determinerede individer eller små avantgardegrupper. Terrorangrebet den 11. september var ingen undtagelse: med ét var verdens eneste supermagt, USA, udfordret på hele to fronter, idet al-Qaeda viste sig i stand til at betjene sig af massemediernes kraftfulde billedmaskiner samt forvandle passagerfly til veritable masseødelæggelsesvåben. Atta og hans gruppe effektuerede en form for ond, ironisk détournement, da de kidnappede Boeing-ruteflyene - der oprindeligt blev udviklet som bombefly og siden 
omdannet til rutefly - og dirigerede dem ind i WTC. Pludselig var det igen klart, hvordan skyskraberen og flyet, der almindeligvis gør livet behageligt, også er mordvåben og kan medføre voldsom død og ødelæggelse.

Det burde ikke være nogen stor overraskelse: Toget er ikke kun en weekendtur i provinsen, det er også transport til koncentrationslejren, og flyvemaskinen er ikke kun ferie i Spanien, men også bomber over Dresden, Hiroshima og Libanon. Men sådanne overvejelser er der tilsyneladende ikke plads til i en moderne verden, og da slet ikke, når terrorisme og antiterrorisme støder sammen. Alle mobiliseres, og der er ingen tid til refleksion. Det er ikke muligt at spørge til voldens årsag og sammenfaldet mellem stat og terror. Terrorens og terrorbekæmpelsens tid er en evig nutid, billederne af død og ødelæggelse tilintetgør klokkens stille samtidighed og erstatter den med 'NU'. Nu skal der handles! Hvilken side er du på?! Sprogets eftertænksomhed afløses af billedets evige øjeblikkelighed. Et konstant bombardement gør det umuligt at stoppe op. ${ }^{20}$

Såvel brugen af to og ikke blot ét passagerfly - som sikrede at alverdens tv-kameraer var rettet mod World Trade Center, da det andet fly 18 minutter efter det første fly ramte bygningen - som eksponeringen af begivenheden på alverdens tv-skærme vidner om terroristernes bevidsthed om, hvorledes billeder i dag spredes øjeblikkeligt og på den måde binder kloden sammen. Aktionen forudsatte ganske enkelt, at kameraerne var rettet mod tårnene. På den måde var massemedieringen en integral del af aktionen.

Inden for terrorismens historie om gerningens propaganda må destruktionen af World Trade Center være noget nær den ultimative aktion. Aldrig før har nogen været i stand til så effektivt at få lemlæstelse og marketing til at gå op i en højere enhed. Al-Qaedas navn stod printet med stort i blod og pixels. Det vigtigste var således heller ikke at dræbe så mange som muligt eller at sætte USA's økonomiske kredsløb ud af kraft, det vigtigste var at erobre tv-skærmene og sprede budskabet, at den nordamerikanske stat var blevet ramt lige midt i hjertet og havde lidt et spektakulært nederlag.

Den tyske komponist Karlheinz Stockhausen forargede de i forvejen oprørte sind, da han kom til at udtale, at terrorangrebet den 11 . september var det ultimative avantgardekunstværk. ${ }^{2 \mathrm{r}}$ Komponisten trak senere sine udtalelser tilbage, men det betyder imidlertid ikke, at udtalelsen ikke har noget på sig. Ud over at sige noget om avantgardens samfundskritiske og ikonoklastiske tendenser, så fortæller den os noget om målet for terrorangrebet. Wall Street er ikke hvilket som helst sted, og dets virkelighed er mere end blot materiel. Wall Street er hjertet i den kapitalistiske $\varnothing$ konomi, derfra pumpes værdi rundt i systemet. Derfor oversteg virkningen af angrebet langt antallet af døde; angrebet fandt sted lige midt i den kapitalistiske verdens Ny Babylon. At terroristerne havde ret, at billederne af de sammenstyrtede tårne rystede den amerikanske nation, synes de efterfølgende krigshandlinger at bekræfte til overmål. Reaktionen lod nemlig ikke vente længe på sig; den amerikanske præsident erklærede, at USA nu var involveret i en uendelig, altomfattende krig mod terror. 


\section{Terror, stat og kapitalisme}

Den konstante gentagelse af denne term, terror, forklarer ikke ret meget, men den har også primært til funktion at placere skylden et andet sted, gøre os til ofre og derved fritage os alle for ansvar. Som den amerikanske antropolog Allen Feldman anfører, blev terrorangrebet forvandlet til oprindelsen, og mulighedsbetingelserne for konflikten blev skjult i den efterfølgende hævnaktion..$^{22}$ Det er den store fortælling i dag: at kapitalismen fungerer helt af sig selv, lige meget hvad den enkelte gør, uanset om vedkommende fabrikerer landminer, udfærdiger låneaftaler eller serverer drinks. De, der døde den morgen i World Trade Center, har således ikke noget at gøre med den måde, verden er på. Vi er gud ske tak og lov alle fritaget for skyld. ${ }^{23}$ Som Slavoj Žižek skriver i bogen Violence, forbliver ikke blot det kapitalistiske systems iboende strukturelle vold usynlig, det gør den enkeltes bidrag til opretholdelsen af den også. ${ }^{24} \mathrm{At}$ forestille sig, at terrorangrebet på World Trade Center og drabet på de børsmæglere, der arbejdede der, underminerer kapitalismen, er uden tvivl en illusion, men det er ikke mindre illusorisk at foregive, at de, der døde den morgen, ikke har noget at gøre med den måde, verden fungerer på. Selvfølgelig har de det, og det er derfor, at det er muligt at gøre tingene anderledes, at reproducere verden på en anden måde. Som Debord ville pointere: Der er en totalitet, og det er os, der genskaber den hver eneste dag, selvom den konstant undslipper os og efterlader os adskilt og passive.

Men henvisningen til terror og terrorist bekræfter blot, at den enkelte intet kan gøre, at den enkelte er prisgivet kræfter, der er større end vedkommende, og at vi derfor har brug for staten til at beskytte os. I kampen mod den ulokaliserbare trussel, terroren, fremstår staten som det skjold, der beskytter befolkningen mod det ukendte. Som den italienske situationist Gianfranco Sanguinetti skriver: "Befolkningen [...] skal erklære sig enig i, at den har behov for staten, som den må give de videst mulige beføjelser for at gøre staten i stand til effektivt at klare det fælles forsvar mod den obskure, mystiske, falske, skånselsløse, og kort sagt, kimæriske fjende." ${ }^{25}$ Men distinktionen mellem stat og terror er aldrig blot neutral, og staten er selv grundlagt på og opretholdes gennem brugen af vold. ${ }^{26}$ Ikke desto mindre defineres terrorismen nu som statens fjende par excellence. På den måde kan nationalstaten pludselig fremstå selvindlysende konfronteret med de globaliseringsbevægelser, der ellers truer med at gøre den overflødig. Terroristen er derfor nationalstatens ideelle fjende, idet terroristen retfærdiggør alt: overvågning og kontrol, arrestationer, censur og suspendering af retsstatens principper. Den politiske strid mellem konkurrerende partikulære dele af en orden suspenderes til fordel for patruljering. Som den italienske filosof Giorgio Agamben har formuleret det, risikerer staten selv at agere terroristisk, når dens eneste formål er sikkerhed. ${ }^{27}$

\section{Den store hammer og efterbilledet}

USA måtte svare igen på 9/11. Som Retort formulerer det: "Den spektakulære stat er tvunget til at finde på et passende svar på nederlaget den 11. september." ${ }^{28}$ Men det har vist sig uendeligt svært for modangrebet at nå de samme symbolske højder som den morgen i september. Tilintetgørelsen af et af de mest repræsentative steder 
i USA var en nedværdigelse af amerikanske værdier i islams navn. Men i modsætning til i antikken, hvor et imperium konfronteret med barbarer altid sørgede for også at lægge fjendens templer og idoler i ruiner, så har USA endnu ikke kunnet få sig selv til at bombe Mekka eller andre hellige steder. I et første moment var det Osama Bin Laden, der måtte stå for skud, og jagten gik ind i Afghanistan. Men da Afghanistan i forvejen var totalt ruineret, og da al-Qaeda fungerede bedst som en usynlig trussel, der legitimerede stadig nye sikkerhedstiltag, var det svært at få fat i de rigtige billeder af amerikansk sejr. Derfor blev det naturligt Irak og Saddam Hussein, der længe havde været en sten i skoen på amerikanske neokonservative, der stod for skud. Da såvel Bin Laden som talebanernes Mullah Omar i mellemtiden var forsvundet sporløst i bjergene mellem Pakistan og Afghanistan og derfor ikke kunne fremvises, blev Saddam altså målet, selvom det irakiske regime ikke spillede nogen som helst nævneværdig rolle i forhold til den islamiske terrorisme. Den indre stabilitet i Saudi Arabien, de Forenede Arabiske Emirater og Pakistan, som er de lande, der i virkeligheden huser og finansierer de radikale islamister, er vigtigere i den aktuelle situation. USA er nødt til at tage hensyn til sine allierede i Mellemøsten for at undgå, at regionens underkastede for alvor får endnu mere negativ energi. Derfor har den amerikanske kapital reelt ikke været i stand til at gøre noget for at ordne problemet. Løsningen har derfor været først at forvandle Afghanistan og siden Irak til ruiner. Den politiske udfordring, som terrorangrebet er et symptom på, blev først forsøgt tacklet som en politiaktion og siden eskalerede det til regulær krig, besættelse og imperialisme. USA fandt den store hammer frem. Men i det nye årtusindes apokalyptiske billedkrig har USA dårlige kort, og det er endnu ikke lykkedes at fjerne billedet af de to tårnes fald. Og selv tilfangetagelsen af Saddam fjernede ikke efterbilledet af sammenstyrtningen af de to monolitter midt i New York. Den amerikanske stat blev fanget med bukserne nede og har siden forsøgt at dække over sin rådvildhed ved at fare hårdt frem i jagten på billeder af sejrrige amerikanske soldater.

\section{Billed- og krigsmaskine}

Billedkatastrofen den 11. september 2001 og den efterfølgende jagt på billeder af en sejrende amerikansk stat har medført, at der er blevet udøvet en hidtil uset kontrol med billeder fra slagmarken i Afghanistan og Irak, og at de billeder, der er blevet cirkuleret, har tenderet imod at have en særlig karakter, der reelt gør krigens effekter usynlige. ${ }^{29}$ Selvom nye lettilgængelige billedteknologier har gjort det muligt for menige soldater i felten at tage fotografier og på den måde fungere som en art (amatør) krigsfotografer, så er det sjældent, at de fotografier, der kommer frem, viser ret meget. Men det sker. Et eksempel er selvfølgelig fotografierne fra Abu Ghraib-fængslet i Bagdad, hvor amerikanske soldater mishandlede irakiske fanger og tog billeder af det. ${ }^{30}$ Fotografierne fra fængslet er et eksempel på, at militærets kontrol med billeder ikke altid er effektiv. Det er dog snarere undtagelsen end reglen, at militæret ikke bestemmer, hvilke billeder der skal tages og cirkuleres. Som den amerikanske krigsfotograf Zorian Miller forklarer i et interview, gør militæret det næsten umuligt at vise, hvad han kalder "krigens virkelighed". ${ }^{\text {I }}$ Millers eksempel er, at ud af de over 
4.000 amerikanske soldater, der er blevet dræbt i Irak, har den amerikanske offentlighed kun set billeder af de fem af dem. Forholdet mellem militæret og pressen er da også særdeles tæt. Den irske journalist Alexander Cockburn afslørede allerede i 2000, at CNN havde ansat en håndfuld medarbejdere, der samtidig var en del af det psykologiske forskningsteam på den amerikanske kaserne, Fort Bragg. ${ }^{32}$

Ud over kontrollen med medierne forsøger militæret også at styre den enkelte soldats billedproduktion. Med udgangspunkt i læren fra Vietnam-krigen, hvor den hjemlige offentlighed langsomt lod sig mobilisere til en omfattende krigsmodstand bl.a. takket være billeder af døde amerikanske soldater, forbød den daværende forsvarsminister Donald Rumsfeld i 2004 mobiltelefoner med kamera, efter at der havde cirkuleret fotos af kister svøbt i Stars and Stripes med døde amerikanske soldater. ${ }^{33}$ Samtidig har det amerikanske militær blokeret for al adgang til internetsider som YouTube og MySpace fra hærens computere, i stedet tilbydes soldaterne mulighed for at oploade billeder på hærens egne hjemmesider, og hæren har samtidig oprettet sin egen side på YouTube med videoer fra Irak. ${ }^{34}$

Som den tyske kunsthistoriker Otto Karl Werckmeister beskriver i sin bog Der Medusa Effekt. Politische Bildstrategien seit dem 11. September er langt størstedelen af de billeder, som den vestlige offentlighed får at se, således tømt for indhold: Ingen billeder får lov til at vise krigens virkelighed og de mange hundredetusinder af døde, men bekræfter blot den officielle version af historien, ifølge hvilken de onde kræfter er blevet besejret eller er trængt i defensiven..$^{35}$ Som den engelske visualitetshistoriker Nicholas Mirzoeff formulerer det: "Det, der i retrospekt var bemærkelsesværdigt [ved krigen i Irak] var fraværet af egentligt mindeværdige billeder." ${ }^{36}$

Ifølge Werckmeister giver det nu mening at tale om, at der eksisterer forskellige billedsfærer: en operationel [operativen] billedsfære og en informationsorienteret [informativen] billedsfære. Den operationelle billedsfære er det virtuelle rum, som de nye digitale medier har muliggjort, hvor billeder produceres, behandles og lagres som data. Disse billeder er ofte en form for kontrolbilleder, det være sig overvågningsbilleder eller irisscanninger. Denne operationelle billedsfære er utilgængelig for den bredere offentlighed, den er, som Werckmeister skriver, "reelt usynlig". ${ }^{37}$ De billeder, som den informationsorienterede sfære stiller til rådighed for offentligheden, er et yderst selektivt udvalg af de billeder, som den operationelle billedsfære producerer. De billeder, der således når en bredere offentlighed, udgør ifølge Werckmeister en meget lille del af de billeder, som optages, produceres og genereres. Der er tale om en generel udvikling, men den er blevet voldsomt intensiveret af krigen mod terror, hvor adgangen til billeder har været yderst begrænset og reduceret til relativt få, ofte reproducerede fotografier, diagrammer og kort, der næsten altid er tømt for mennesker. Et eksempel er de ofte benyttede kort, der, idet de repræsenterer krigen og konkrete troppebevægelser ved hjælp af forskelligt farvede pile, reducerer krigens frygtelige realitet til en art vejrudsigt, hvor vi aldrig ser de mennesker, der bliver fanget i regnen (af kugler). Som den amerikanske anarkosufist og forfatter Peter Lamborn Wilson formulerer det: "I den hyperreelle krig er de døde kroppe pist væk." ${ }^{38}$

CNN's medrejsende korrespondent David Bowden følte sig under en live-udsendelse, hvor han stod med en mikrofon i hånden og en blå hjelm på hovedet foran 
en sanddyne omgivet af amerikanske marineinfanterister, i forbindelse med invasionen af Irak forpligtet til at forsikre tv-seerne om, at han vitterligt var ved fronten: "Dette her er ikke en sæbeopera. Dette her er ikke tv. Det er krig." 39

Samtidig med at den vestlige offentligheds adgang til billeder af krigen altså er yderst begrænset, og at de billeder, der kommer frem, næsten alle er rene propagandaudsagn, så fungerer billeder som en integral del af den konkrete krigsførelse, idet de benyttes til at generere koordinater for mål, som automatisk overføres til fjernstyrede våben. Ifølge Werckmeister er vi i den paradoksale situation, at der ikke eksisterer særligt mange billeder af det, der faktisk finder sted på jorden, billeder af de ubeskrivelige lemlæstelser og den smerte, krigen forvolder, til gengæld findes der billeder, der forudgriber de kommende aktioner, hvis konsekvenser dog forbliver stort set usynlige..$^{40}$ Det menneskelige øje er på den måde blevet erstattet med den militære billedteknologis umenneskelige øje, der, som Medusa, dræber, idet det ser.

Mønstereksemplet på den udvikling, hvor vi kun ser "rensede billeder", er ifølge Werckmeister den allerede omtalte embedded journalism, hvor journalister får lov til at følge hærenheder i felten. Denne praksis genererer ganske vist billeder, men ganske bestemte billeder, der nødvendigvis reproducerer militærets synsvinkel, idet fotograferne og reporterne lever sammen med soldaterne og oplever det samme, som de gør. Når pressefotografer og journalister følger med amerikanske, britiske eller danske soldater rundt i felten, adopterer de næsten nødvendigvis deres synspunkt, og enhver ansats til kritisk stillingtagen forsvinder. Derudover er journalisterne underlagt streng censur, og de er endda på forhånd blevet programmerede til opgaven: I perioden op til invasionen af Irak deltog hundredevis af amerikanske journalister således i træningsprogrammer, som det amerikanske forsvarsministerium tilrettelagde. ${ }^{4 I}$

Mange af de mest reproducerede billeder fra krigen havde til formål at bekræfte USA's sejr. Som den irsk-amerikanske politiske geograf Gearóid Ó Tuathail skriver: "Siden september 2001 har den amerikanske udenrigspolitik været drevet af et begær efter at hævne 9/11 og hævde fantasien om, at Amerika er den eneste tilstedeværende supermagt, og at alle århundreder er det amerikanske århundrede." ${ }^{42}$ Behovet for at eksorcere billederne af de to tårne i frit fald motiverede den amerikanske krigsmaskine til ved flere lejligheder at iscenesætte en række optrin, hvor ingen kunne være i tvivl om, at krigen nu var vundet: Bush lander på et hangarskib i den Persiske Golf, Bush serverer kalkun, Saddam-statuen midt i Bagdad rives ned. Som Nicholas Mirzoeff skriver, var det næsten som om, billedet af amerikansk sejr var vigtigere end en reel militær sejr. "[K]rigsbilledet performer den amerikanske sejr som et billede, og så er den potte ude af verden." ${ }^{43}$ Fremvisningen af Saddam Hussein, efter at han var blevet taget til fange, var et af disse øjeblikke. Som den amerikanske visualitetsteoretiker W.J.T. Mitchell skriver, var formålet med billederne, hvor Saddam får undersøgt sine tænder, at diktatoren skulle vises frem på en ydmygende måde, men uden at der af den grund var tale om tortur fra amerikansk side. ${ }^{44}$ Billederne af Saddam med åben mund og en plasticbehandsket hånd, der lyser ind i munden på diktatoren, gik verden rundt. USA og hele verden kiggede nu direkte ind i hovedet på den onde diktator, sejren var total. Saddam havde gemt sig 


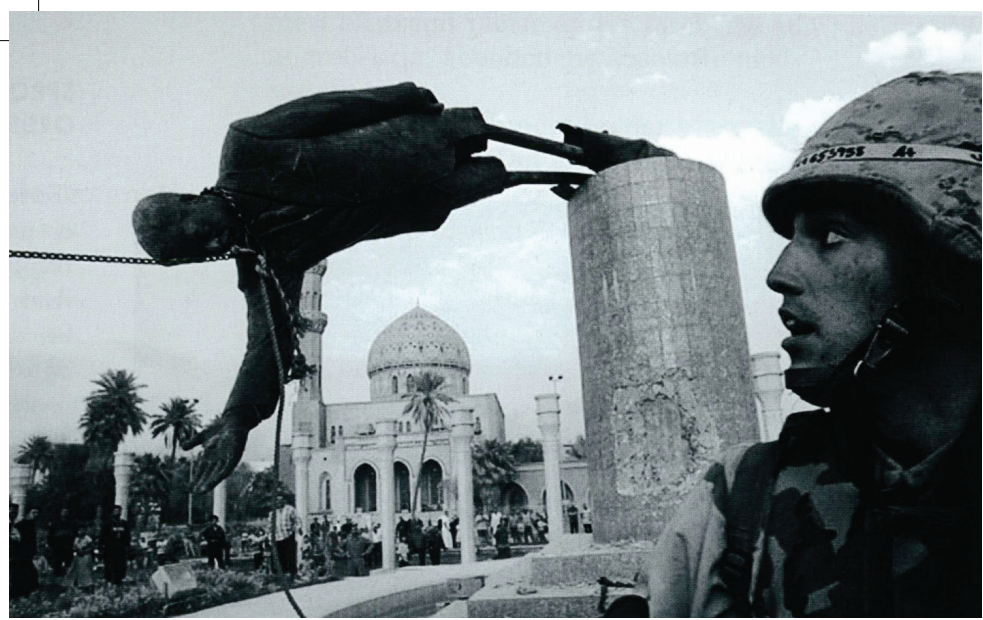

i en underjordisk hule, men nu var der ikke flere overraskelser, der blev så at sige kastet lys over alle de hemmeligheder, der måtte gemme sig i diktatoren(s hoved): onde planer, cyanidkapsler eller andet.

Ved den første fremvisning af videosekvensen udtalte den amerikanske statsholder i Irak, Paul Bremer, triumferende: "Vi har ham!" ["We got him!"]. At det egentlig allerede fremgik af billederne afholdt ikke Bremer fra at fremsætte sin kommentar, der blot bekræfter billedet. Pointen er evident: Det, vi ser, er hinsides diskussion, vi præsenteres blot for fakta. Det er ikke nødvendigt for beskueren at danne sin egen mening om billedet eller fortolke det, alt er serveret, alt er åbenbart: "Vi har ham!" Kommentaren og fotografiet slutter helt tæt, og Bremers udtalelse giver os meningen med billedet: De gode har fanget den onde, som nu viser sig slet ikke at være den farlige diktator, han troede, han var, men bare en gammel træt langskægget mand, der gemmer sig i en hule. Man må spørge sig selv, hvilken politik sådanne billeder og kommentarer lægger op til? Og hvorfor de stort set aldrig kommenteres kritisk, men blot viderebringes følgagtigt af de fleste internationale medier inklusive de danske. ${ }^{45}$

USA og dets allierede har ved gentagne lejligheder erklæret krigen for vundet, hvad der dog ikke har afholdt den irakiske modstandsbevægelse og eksternt støttede militante islamiske grupper fra at fortsætte kampen. Hvor mange, der er døde, er uvist, men det anerkendte medicinske tidsskrift The Lancet mente, at det allerede i 2006 drejede sig om op mod 665.000 mennesker, hvoraf langt de fleste var civile. ${ }^{46}$

\section{Black Out}

Terrorangrebet den 11 . september og den efterfølgende krig mod terror og invasionerne af Afghanistan og Irak vidner om et system i ubalance. Den amerikanske kapital synes ikke rigtig at kunne overvinde chokket fra 9/11, og den kan slet ikke løse de grundlæggende problemer, som terrorangrebet er et udtryk for. Kapitalen har aktuelt problemer med at skabe værdi. Som verdenssystemteoretikeren Immanuel Wallerstein skriver, så er vi vidner til en omfattende krise i det globale kapitalistiske system: "De mekanismer, som er blevet brugt til at skabe relativ ligevægt i systemet, fungerer ikke længere [...] Det betyder, i hegelianske termer, at systemet ikke læn- 


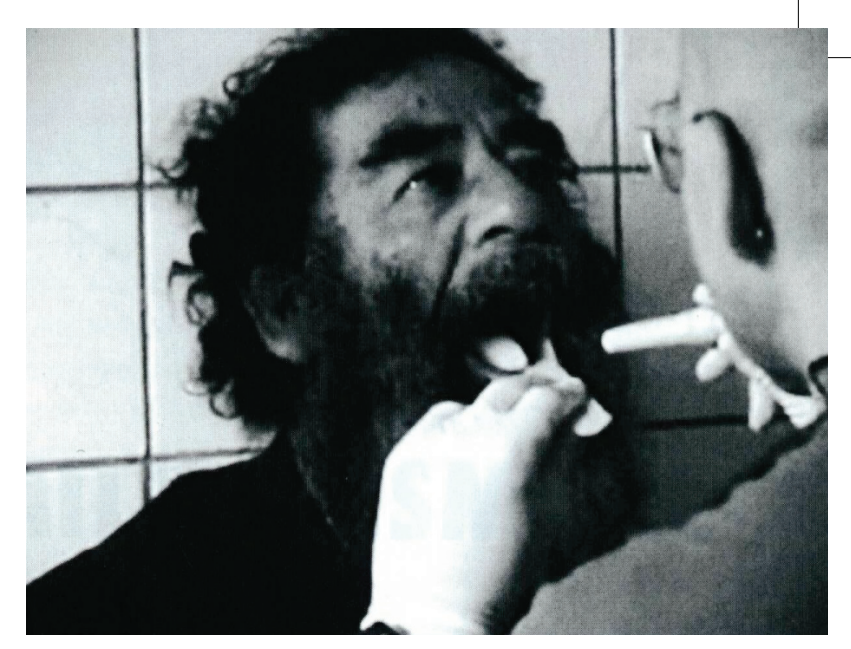

gere kan rumme sine modsigelser." ${ }^{47}$ Det kommer til udtryk i den tilbagetrækning, der har fundet sted, hvor det nuværende verdenssystem befæster sig i USA, Europa og Japan, lægger resten af verden brak og blot henter ressourcer i disse områder, når det er muligt. Som bl.a. Naomi Klein har vist i tilfældet Irak, så er der ingen intentioner om at opbygge noget eller skabe orden. ${ }^{48} \mathrm{Vi}$ er mest af alt konfronteret med en karikatur af økonomisk liberalisering, hvor det kun kan resultere i katastrofe, når en svag, statsstyret økonomi privatiseres på få uger. I Irak er frihandel lig med ulykke for langt de fleste indbyggere, og det er kun firmaer som Halliburton og få lokale med forbindelser til den udenlandske besættelsesmagt, der får noget ud af det. Vi er med andre ord langt fra Marshall-planens dage. Den nuværende periode minder snarere om mellemkrigstiden, hvor der skete en sammentrækning og en reduktion i cirkulationen af varer og arbejdskraft. Alle tegn i måne og stjerner tyder på en langvarig krise og flere militære konflikter. I den situation er det svært at opfinde og opretholde visuel modstand for slet ikke at sige noget sammenhængende om muligheden for skabelsen af et alternativt politisk projekt med et kosmopolitisk perspektiv. ${ }^{49}$ Som Retort i forlængelse af Debord har pointeret, synes vi konfronteret med en paradoksal situation af fortidighed og progression, på den ene side har vi været vidner til genkomsten af religionskrige, der nærmest synes taget direkte ud af det 17. århundrede, og på den anden side er situationen kendetegnet ved en stadig mere forfinet brug af visuelle produktionsteknikker, der udstyrer såvel krigen som det politiske med en særlig billedside. ${ }^{50}$ Aktuelt synes skærmkapitalismen primært at være grobund for religiøs fundamentalisme og for andre reaktionære kræfter.

Tak til Erik Granly, Jesper Lohmann og Jacob Lund for kommentarer til manuskriptet.

\section{Noter}

I Walter Benjamin: "Kunstværket i dets tekniske reproducerbarheds tidsalder" [1936], oversat af Jørgen Holmgaard, in K\&K, nr. 79, 1994, p. 36.

2 Jean-Luc Nancy: "De l'un et de la hiérarchie", in Lignes, nr. 8, 2002, p. 72.

3 Giuliana Sgrena: "Lustro di guerra", in Il Manifesto, den 20. marts 2008. 
4 Thomas Lauritzen: "Danmark forærer NATO en Tv-kanal”, in Politiken, den 2. april 2008.

5 Walter Benjamin: "Kunstværket i dets tekniske reproducerbarheds tidsalder", p. 35.

6 Jvf. Enzo Traverso: La violence nazie. Une généalogie européenne, Paris: La Fabrique, 2002.

7 Jvf. Zygmunt Bauman: Modernitet og Holocaust [1989], oversat af Ole Lindgård Henriksen, København: Hans Reitzels Forlag, 1994.

8 Jvf. Alice Yeager Kaplan: Reproductions of Banality: Fascism, Literature, and French Intellectual Life, Minneapolis: University of Minnesota Press, 1986.

9 Jvf. Benedict Anderson: Imagined Communities: Reflections on the Origin and the Spread of Nationalism, London \& New York: Verso, 1983.

Io Guy Debord: Skuespilsamfundet [1967], oversat af Ole Klitgaard, København: Rhodos, 1972, p. 10 (\# 1). Debord plagierer den første sætning fra Das Kapital: "I de samfund, hvor den kapitalistiske produktionsmåde hersker, viser rigdommen sig som en uhyre vareophobning, og den enkelte vare som dens elementarform.” Marx: Kapitalen [1867], oversat af Gelius Lund, København: Rhodos, 1970, p. 128.

II Den amerikanske arkitekturhistoriker Beatriz Colomina beskriver i Domesticity at War (Cambridge, MA \& London: MIT Press, 2007), hvorledes fjernsynet i 1950'ernes USA var med til at sløre grænsen mellem privat og offentlig og gøre hjemmet til en potentiel krigszone.

I2 Debord: Skuespilsamfundet, p. 13 (\# 12).

I3 Thomas Keenan: "Mobilizing Shame", in South Atlantic Quaterly, nr. 2/3, 2004, p. 442.

I4 Retort (Ian Boal, T. J. Clark, Joseph Matthews \& Michael Watts): Afflicted Powers: Capital and Spectacle in a New Age of War, London \& New York: Verso, 2005, p. 26.

I5 Slavoj Žižek: Welcome to the Desert of the Real, London \& New York: Verso, 2002.

I6 For en analyse af Bin Ladens islamisme i forhold til spørgsmålet om kapitalkritik og antiimperialisme, se Mikkel Bolt: "Uvidenhedens tidsalder. Noter om antikapitalisme, avantgarde, billedpolitik, kolonisering og militant islamisme", in Ny Mutant, nr. 1, 2007, pp. 7-17, idem: "Hvad gør vi med Bin Laden? De antihegemoniske bevægelser og den islamiske fundamentalisme", in Det Ny Clarté, nr. 6, 2008, pp. 64-67.

I7 Jonathan Barker: The No-Nonsense Guide to Terrorism, London \& New York: Verso, 2002, p. 10.

I8 Margaret Thatcher citeret i Jeff Lewis: Language Wars: The Role of Media and Culture in Global Terror and Political Violence, London \& Ann Arbor, Michigan: Pluto, 2005, p. 7.

I9 Jacques Derrida: "Autoimmunitet. Virkelige og symbolske selvmord", in Jürgen Habermas \& Jacques Derrida: Filosofi i terrorens tid. Samtaler med Giovanni Borradori [2003], oversat af Rasmus Navntoft Pedersen \& Mikkel Bagge Lange, København: Informations Forlag, 2005, p. 123.

20 Jvf. Giorgio Agamben: "In questo esilio", in: Mezzi senza fine. Notesulla politica, Torino: Bollati Boringhieri, 1996, pp. 95-96.

2I For en transskription af hele pressekonferencen, hvor Stockhausen fremførte sine betragtninger over 9/11 som det ultimative kunstværk, se “'Huuuh’ Das Pressegespräch am 16. September 2001 im Senatszimmer des Hotel Atlantic in Hamburg", MusikTexte, nr. 91, 2002, pp. 69-77.

22 Allen Feldman: "On the Actuarial Gaze: From 9/11 to Abu Ghraib", in Cultural Studies, nr. 2, 2005, pp. 213-214.

23 For en skarp kritik af denne forestilling, se Ulrich Raulffs interview med den franske filosof Jacques Derrida: "Niemand ist unschuldig", Süddeutschen Zeitung, den 24. september 2001.

24 Slavoj Žižek: Vold. Seks skæve refleksioner [2008], oversat af Brian Benjamin Hansen, Århus: Forlaget Philosophia, 2008, pp. 10-12. 
prima volta divulgata (Milano: 1979), n.p.

26 For ikke at tale om de utallige eksempler på egentlig statsterrorisme; for en god introduktion til dette emne med særligt fokus på USA, se artiklerne samlet i Alexander George (red.): Western State Terrorism, Cambridge: Polity Press, 1991. En aktuel præsentation af USA's meritter i denne henseende kan findes i Noam Chomsky: Hegemoni og overlevelse. Amerikas jagt på verdensherredømmet [2003], oversat af Henrik Stamer Hedin, Århus: Forlaget Klim, 2006.

27 Jvf. Giorgio Agamben: "Sicurezza e terrere", in Il manifesto, 27. oktober 2001. Se også Mikkel Bolt: "Antiterrorisme som regeringsteknik", in Morten Brænder \& Mikkel Thorup (red.): Antiterrorismens idéhistorie. Stater og vold i 500 år, Århus: Aarhus Universitetsforlag, 2007, pp. 253-260.

28 Retort: Afflicted Powers, p. 34.

29 Jvf. David Miller (red.): Tell Me Lies: Propaganda and Media Distortion in the Attack on Iraq, London \& Sterling, Virginia: Pluto Press, 2004. I den ellers udmærkede artikel "Krigen på billeder. Visuel krigsførelse i digitaliseringens og globaliseringens tidsalder" (in Kritik, nr. 186, 2007, pp. 7-17) tegner den danske kulturhistoriker Mette Mortensen et bemærkelsesværdigt positivt billede af forholdet mellem synliggørelse af og kontrol med krigsbilleder.

30 Jvf. Stephen Eisenman: The Abu Ghraib Effect, London: Reaktion Books, 2007. Se desuden Mikkel Bolt: "Abu Ghraib: Biopolitikkens æstetisering”, in Lettre International, nr. 4, 2004, p. 82.

3I Nils Thomsen: "Krigen uden ansigt" (interview med Zoriah Miller), in Politiken, den 6. september 2008.

32 Alexander Cockburn: "CNN and Psyops", in Counterpunch, 26. marts 2000, http://www. counterpunch.org/cnnpsyops.html.

33 For en kritisk analyse af de amerikanske mediers rolle i formidlingen af Vietnam-krigen, se Daniel Hallin: The Uncensored War: The Media and Vietnam, Oxford: Oxford University Press, 1986. Ifølge Hallin forstod stort set alle større mainstreammedier sig i krigens begyndelse mindre som reportere og mere som patrioter.

34 Patrick Jackson: "Controlling the Bandwidth of War", in BBC News, 15. maj 2007, http://news. bbc.co.uk/2/hi/americas/6657309.stm og Laura Smith-Sparks: "US Military takes Iraq War to YouTube", BBC News, 14. maj 2007, http://news.bbc.co.uk/2/hi/americas/6639401.stm.

35 Otto Karl Werckmeister: Der Medusa-Effekt. Politische Bildstrategien seit dem 11. September 2001, Berlin: Form + Zweck Verlag, 2005.

36 Nicholas Mirzoeff: Watching Babylon: The War in Iraq and Global Visual Culture, New York \& London: Routledge, 2005, p. 68.

37 Ibid., p. 7.

38 Peter Lamborn Wilson: "The Information War", 1995, www.t0.or.at/hakimbey/infowar.htm.

39 Jvf. Martin Burcharth: "Irak: Medier er medansvarlige for krigen", in Information, 24. marts 2003.

40 Som Zygmunt Bauman udtaler, kan nutidens soldater "sove roligt, de bliver ikke holdt vågne af nogen samvittighedskvaler. [...] Piloterne-der-er-blevet-computer-operatører ser næsten aldrig deres ofre i øjnene. [...] Nutidens professionelle soldater ser ingen kroppe og ingen sår." "Wars of the Globalization Era", in European Journal of Social Theory, nr. 1, 2001, p. 27.

4I Jvf. Joe Strupp: "U.S. Military Tries to Make Peace With Press", in Editor \& Publisher, 7. januar 2003, http://www.editorandpublisher.com/editorandpublisher/headline/article_display. jsp?vnu_content_id=1788729.

42 Gearóid Ó Tuathail: “Just Out Looking for a Fight': American Affect and the Invasion of Iraq”, in Antipode, nr. 5, 2003, p. 868. 
43 Nicholas Mirzoeff: Watching Babylon, p. 77.

44 W. J. T. Mitchell: "Cloning Terror: The War of Images 2001-4", in Diarmuid Costello \& Dominic Willsdon (red.): The Life and Death of Images: Ethics and Aeshetics, London: Tate Publishing, 2008, p. 193.

45 For en kritisk diskussion af den danske presses formidling af Irak-krigen, se Jørgen Bonde Jensens fremragende Politiken og krigspolitikken (København: Babette, 2007), hvor Bonde Jensen analyserer, hvorledes militarismen gennemtrænger det danske samfund. Derudover bør Carsten Juhls ikke mindre imponerende Globalæstetik. Verdensfølelsen og det kosmopolitiske perspektiv (København: Det Kongelige Danske Kunstakademi, 2007) inddrages i den kommende analyse af den politiske kultur i Danmark post 9/11. For en empirisk og statistisk analyse af de danske mediers dækning af invasionen af Irak, se Nete Nørgaard Kristensen \& Mark Ørsten: "Danske mediers dækning af Irak-krigen 2003 - i tal og store træk”, in Nete Nørgaard Kristensen \& Mark Ørsten (red.): Krigen i medierne, medierne i krig, Fredriksberg: Forlaget Samfundslitteratur, 2006, pp. 31-62. Kristensen og Ørsten opsummerer deres undersøgelse således: “Trods deres antagelige politiske uafhængighed og på trods af deres indsats var de danske medier i sidste ende ikke i stand til at forblive uafhængige af hverken de nationale eller internationale politiske dagsordener eller af de væsentlige koalitionsparter, men blev i stedet stemmer for disse kilder og for deres version af krigens virkelighed", p. 59.

46 Gilbert Burnham, Riyadh Lafta, Shannon Doocy \& Les Roberts: "Mortality after the 2003 Invasion of Iraq: A Cross-Sectional Cluster Sample Survey", in The Lancet, 11. oktober 2006, http:// www.thelancet.com/webfiles/images/journals/lancet/s0140673606694919.pdf. Som den svenske forfatter Sven Lindqvist beskriver i sin magistrale $\mathrm{Nu}$ dog $\mathrm{du}$, Bombernas århundrade (Stockholm: Bonniers, 1999) så føres moderne krige altid uden respekt for internationale love, og det er altid civile, der lider mest. For en diskussion af, hvorledes forestillingen om den civile kun gælder ens egne statsborgere og ikke andre civile, som derfor kan dø som en form for nøgent liv, se Derek Gregory: "Den civile, en død forestilling?”, oversat af Morten Visby, in Øjeblikket, nr. 47, 2006, pp. 7-10.

47 Immanuel Wallerstein: The Decline of American Power: The U. S. in a Chaotic World, New York: The New Press, 2003, p. 230.

48 Jvf. Naomi Klein: Chokdoktrinen. Katastrofekapitalismens opkomst [2007], oversat af Steen Fill, Århus: Klim, 2008.

49 Formuleringen, der går på at opfinde en visuel modstand, er hentet hos den engelske kunsthistoriker Francis Frascina: "Inventing and Sustaining a Visible Resistance", in Peace Review, nr. 4, 2003, pp. 491-498.

50 Retort: Afflicted Powers, pp. 14-15. 